Aroma profile and sensory quality of honey brandy produced by the fermentation process with immobilized yeast cells

Aromatski profil i senzorska kvaliteta medne rakije proizvedene fermentacijom s imobiliziranim kvascima

Miličević, B., Ačkar, Đ., Babić, J., Jozinović, A., Miličević, R., Petošić, E., Kujundžić, T., Šubarić, D.

Poljoprivreda/Agriculture

ISSN: $1848-8080$ (Online)

ISSN: 1330-7142 (Print)

http://dx.doi.org/10.18047/poljo.24.2.5

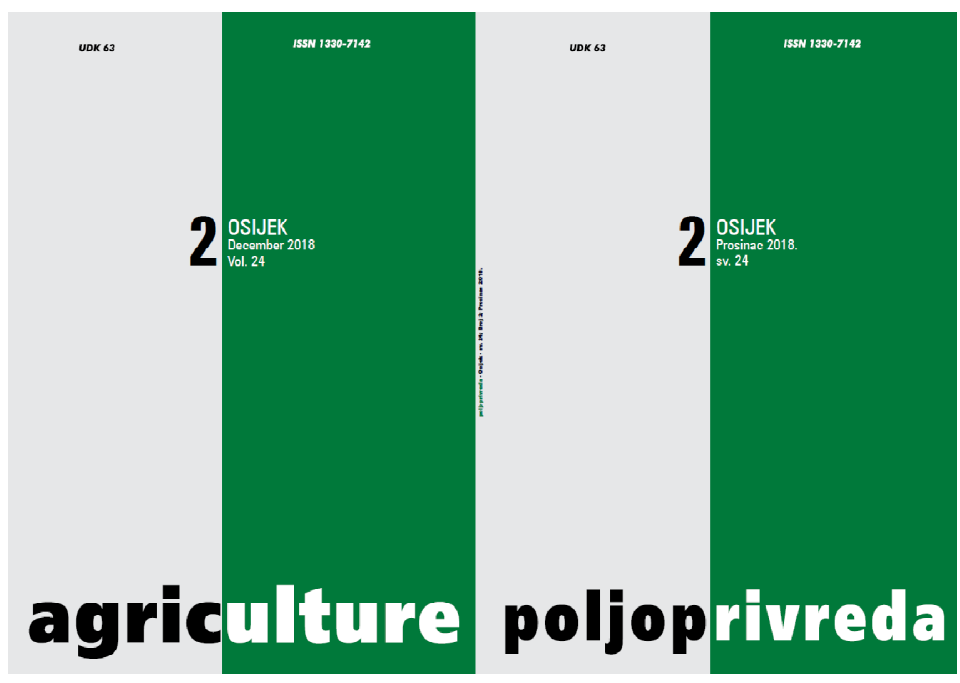

Fakultet agrobiotehničkih znanosti Osijek, Poljoprivredni institut Osijek

Faculty of Agrobiotechnical Sciences Osijek, Agricultural Institute Osijek 


\title{
AROMA PROFILE AND SENSORY QUALITY OF HONEY BRANDY PRODUCED BY THE FERMENTATION PROCESS WITH IMMOBILIZED YEAST CELLS
}

\author{
Miličević, B. ${ }^{(1)}, A c ̌ k a r, \Theta^{(1)}$, Babić, J. ${ }^{(1)}$, Jozinović, A. ${ }^{(1)}$, Miličević, R. ${ }^{(2)}$, Petošić, E. ${ }^{(3)}$, Kujundžić, $T^{(4)}$, \\ Šbarić, $D$. ${ }^{(1)}$
}

Original scientific paper

Izvorni znanstveni članak

\begin{abstract}
SUMMARY
Volatile organic compounds in honey represent a fingerprint of a specific honey and therefore could significantly affect the quality of honey brandy. In addition, during fermentation, yeast synthesise volatiles also affecting aroma and quality of brandy. The aim of this research was to assess the impact of immobilized cell fermentation on volatile aroma of honey brandies produced from acacia and chestnut honey. Aroma profile was determined using GC/FID and sensory analysis was conducted according to German DLG model. The results showed that immobilized cell technique had resulted in honey brandies with lower ester contents, but significantly higher content of volatile organic compounds from honey.
\end{abstract}

Key-words: immobilized yeast cells, honey brandy, aroma, sensory quality

\section{INTRODUCTION}

Honey is probably among the first foods gathered by Homo sapiens and its predecessors. Beverages from fermented honey may well be one of the oldest alcoholic beverages in the history. Honey wine (mead) and honey brandy are deeply rooted in the culture of many nations, especially those nomadic ones, such as the Slavs and especially the old Croats (Bašić, 2006). The quality of these fermented honey products depends on the type of honey, water and additives, as well as the type of fermentation process and yeast selection (Gupta and Sharma, 2009; Anjos et al., 2017).

Alcoholic beverages are complex mixtures mainly comprised of ethanol, water and a large number of minor compounds that may be present in the raw materials or formed during the distinct stages of the manufacturing process such as: alcohols, acids, esters, aldehydes, polyphenols, metals, amino acids, etc. (Rodríguez Madrera and Suárez Vales, 2007). From the chemical point of view, many factors are involved in profiling the quality of fresh honey brandy (those which have not been aged in wood). Also, the honey volatile substances play the important role.
These volatile organic compounds mainly come from groups of chemical compounds such as aldehyde, ketone, acid, alcohol, hydrocarbon, norisoprenoids, terpenes and benzene compounds, furan, pyran and their derivatives. They represent a fingerprint of a specific honey and therefore could significantly affect the quality of honey brandy (Bouseta et al., 1992; Radović et al., 2001; Jerković et al., 2007; Jerković and Marijanović, 2009; Wardencki et al., 2009; Manyi-Loh et al., 2011a, 2011b).

In addition, during fermentation many volatile compounds are formed by metabolic activity of yeast that also influences aroma. The composition of these compounds and their concentration depend largely on stress that yeast is exposed during the fermentation. Immobilized yeast cells are protected from the stress

(1) Prof. Dr. Borislav Miličević, Assoc. Prof. Đurđica Ačkar (dackar@ ptfos.hr), Prof. Dr. Jurislav Babić, Assist. Prof. Antun Jozinović, Prof. Dr. Drago Subarić - Josip Juraj Strossmayer University of Osijek, Faculty of Food Technology Osijek, F. Kuhača 20, HR-31000 Osijek, Croatia (2) Ph. D. Radoslav Miličević, Progresys d.o.o., Ind. Park bb, HR-35400 Nova Gradiška, Croatia, (3) Emil Petošić, Zvečevo d.d., Food Industry, Kralja Zvonimira 1, HR-34000 Požega, Croatia, (4) Toni Kujundžić - Josip Juraj Strossmayer University of Osijek, Faculty of Agrobiotechnical Sciences Osijek, V. Preloga 1, HR-31000 Osijek, Croatia 
and therefore they metabolise glucose more quickly and produce more ethanol. At the same time, activity of some enzymes, such as pyruvate decarboxylase and succinate dehydrogenase decreases, as well as metabolism of amino acids (Nedović et al., 2015).

In addition to fermentation, distillation also influences aroma that will be carried over to the spirit. First, most volatile compounds are distilled in the first fraction or the head, than heart of distillate elaborates spirits and finally the tail comprises compounds with high boiling point. Head and tail are usually re-distilled (RodriguesBencomo et al., 2016). Distillation system influences content and composition of aroma compounds, as reported by Arrieta-Garay at al. $(2013,2014)$.

The aim of this research was to assess the impact of immobilized cell fermentation on volatile aroma of honey brandy using GC/FID analysis (Hewlett Packard 5890 gas chromatograph with a split/splitless injector and FID detector was used. Analysis of wine Hewlett Packard sampler HP 7694 was used for the headspace and sensory analysis, according to German DLG model.

\section{MATERIAL AND METHODS}

Honey

Samples of honey (Robinia pseudoacacia L.- acacia and Castanea sativa L.- chestnut) were taken from "Progresys" d.0.0. and introduced in the technological process of honey brandy production at "Zvečevo" d.d.

\section{Mead fermentation}

Control samples were produced using classical technological procedure with free selected yeast Fermol-Bouqet 125, described previously (Miličević et al., 2017). The average duration of the fermentation under these conditions was 14 days.

The fermentation with selected yeast FermolBouqet 125 immobilized in Ca-alginate gel was also described previously (Miličević et al., 2017). The average duration of fermentation under these conditions was 3 days for each set. The reusability of immobilized cultures was not tested.

For fermentations, $250 \mathrm{~g} / \mathrm{L}$ of honey was used, totally $25 \mathrm{~L}$ of fermentation solution. Yeast was used in concentration of $20 \mathrm{~g} / 100 \mathrm{~L}$ (as advised by manufacturer), Enovit $15 \mathrm{~g} / 100 \mathrm{~L}$.

All samples were taken at the end of fermentation before sedimentation, therefore the samples were insufficiently clear and slightly dull, being appropriate for the selected procedure for the distillate production.

\section{Distillation}

All the selected samples were distilled according to the same distillation protocol in copper clip distillation device according to the traditional brandy distillation protocol (Lukić et al., 2012). Three main distillation fractions were obtained, and only the middle-run part (the 'heart' fraction) was used for further analyses.
After distillation, distillate rested in glass bottles for 30 days.

Each sample was produced in 3 parallels.

\section{Chemical analysis of distillates}

Instrumental analytical techniques were applied on the basis of the European Community Reference Methods for the analysis of brandies used gas chromatography (AOAC, 1995; EEC, 2000; EEC, 2008).

Analysis of volatile aroma compounds was done on a Hewlett Packard 5890 gas chromatograph with a split/splitless injector and FID detector in triplicates. Hewlett Packard sampler HP 7694 was used for the headspace analysis of wine. Analysis conditions were described elsewhere (Miličević et al., 2017).

\section{Sensory analyses}

A sensory analysis of samples was performed by the method of positive ranking according to the German DLG model (Koch, 1986). This model was based on 4 sensorial experiences, marked with grades from 0 to 5 , including 0 , while the average grade is multiplied by the significance factor.

Sensory assessment was conducted in two repetition cycles. Each group had ten qualified professional testers from alcoholic beverages industry, experienced in sensory assessment of distillates, and selected as described by Jellinek (1985).

\section{Statistical analysis of the results}

Statistica $13.3 \AA$ software was used. Results of the chemical analysis were analysed by analysis of variance (ANOVA) and Fisher's least significant difference (LSD) with significance defined at $P<0.05$. To get better insight into influence of the fermentation procedure on aroma and sensory properties, box plots of median values were made, with grouping by procedure (influence of the honey type was not considered in this step).

\section{RESULTS AND DISCUSSION}

The results of GC analysis of the distillates are shown in the Table 1. The fermentation process with immobilized yeast cells resulted in increased content of ethanol in both types of the investigated honey brandy (from 43.22 to $45.89 \%$ vol.). These results obtained for ethanol content are in accordance with the results obtained for wild honey brandy in the investigations of Silva et al. (2017) and Anjos et al. (2017). Furthermore, it is important to notice that the results for ethanol content are in accordance with EU regulation about spirit drinks, stating that the minimum alcoholic strength for honey spirits is $35 \%$ (EEC, 2008). The comparison of median values in Figure 1 shows that this rise of ethanol content in samples fermented with immobilized yeast cells is significant. Similar trend was observed in our previous researches (Miličević et al., 2012; Miličević et al., 2017) and reported by other authors as described in the review by Nedović et al. (2015). 
The content of methanol $(0.14-0.15 \mathrm{mg} / \mathrm{L}$ in classically fermented and $0.04 \mathrm{mg} / \mathrm{L}$ in samples fermented with immobilized yeast cells) was in acceptable range (Nykanen and Suomalainen, 1983; Paine and Dayan, 2001). However, since methanol content in alcoholic beverages is considered an important safety factor (Pohanka, 2016), the fact that applying the fermentation process with immobilized yeast cells resulted in significant reduction of methanol content in honey brandy (Figure 1) is of great importance.

As with previously described parameters, the total extract and acidity were not influenced by honey type used as a raw material (acacia or chestnut) (Table 1). Results for total acidity ranged from 344.10 to 470.85 $\mathrm{mg} / \mathrm{L}$, being in accordance with the results $(40.04$ $\mathrm{mg} / 100 \mathrm{~mL}$ ) published by Silva et al. (2017) for the honey brandy produced from wild honey of the western region of Santa Catarina, Brazil. However, using the fermentation process with immobilized yeast cells significantly reduced both of these parameters (Figure 1), showing the higher degree of fermentation, as was observed in our previous researches on fig (Miličević et al., 2017) and tangerine distillates (Miličević et al., 2012).

Table 1. Selected chemical characteristics of honey distillate samples (mean \pm standard deviation)

Tablica 1. Odabrana kemijska svojstva destilata meda (srednja vrijednost \pm standardna devijacija)

\begin{tabular}{|c|c|c|c|c|}
\hline \multirow{2}{*}{$\begin{array}{l}\text { Analytical parameter } \\
\text { Analitički parametar }\end{array}$} & \multicolumn{2}{|c|}{ Acacia / Bagrem } & \multicolumn{2}{|c|}{ Chestnut / Kesten } \\
\hline & $\begin{array}{l}\text { Classical } \\
\text { Klasični }\end{array}$ & $\begin{array}{l}\text { Immobilized } \\
\text { Imobilizirani }\end{array}$ & $\begin{array}{l}\text { Classical } \\
\text { Klasični }\end{array}$ & $\begin{array}{l}\text { Immobilized } \\
\text { Imobilizirani }\end{array}$ \\
\hline Total extract $(\mathrm{g} / \mathrm{L})$ & $0.06 \pm 0.00^{b}$ & $0.02 \pm 0.01^{\mathrm{a}}$ & $0.06 \pm 0.01^{b}$ & $0.02 \pm 0.01^{\mathrm{a}}$ \\
\hline Total acidity (mg/L) & $470.85 \pm 18.74^{b}$ & $344.10 \pm 2.69^{\mathrm{a}}$ & $470.35 \pm 13.79^{b}$ & $344.60 \pm 1.98^{a}$ \\
\hline Ethanol (\% vol.) & $43.22 \pm 0.04^{\mathrm{a}}$ & $45.89 \pm 0.04^{b}$ & $43.22 \pm 0.04^{\mathrm{a}}$ & $45.87 \pm 0.04^{b}$ \\
\hline Methanol (mg/L) & $0.15 \pm 0.01^{\mathrm{a}}$ & $0.04 \pm 0.06^{\mathrm{a}}$ & $0.14 \pm 0.01^{\mathrm{a}}$ & $0.04 \pm 0.06^{\mathrm{a}}$ \\
\hline Furfural (mg/L) & $0.07 \pm 0.01$ & tr. & $0.07 \pm 0.01$ & tr. \\
\hline 1-Propanol (mg/L) & $2.68 \pm 0.05^{b}$ & $1.80 \pm 0.14^{\mathrm{a}}$ & $2.68 \pm 0.03^{b}$ & $1.81 \pm 0.11^{\mathrm{a}}$ \\
\hline 1-Butanol (mg/L) & $0.18 \pm 0.05^{b, c}$ & $0.09 \pm 0.01^{\mathrm{a}}$ & $0.19 \pm 0.02^{c}$ & $0.10 \pm 0.01^{a, b}$ \\
\hline Isobutyl alcohol (mg/L) & $3.71 \pm 0.14^{b}$ & $3.41 \pm 0.01^{\mathrm{a}}$ & $3.73 \pm 0.10^{b}$ & $3.43 \pm 0.02^{\mathrm{a}}$ \\
\hline Isoamyl alcohol (mg/L) & $8.80 \pm 0.02^{b}$ & $6.15 \pm 0.25^{\mathrm{a}}$ & $8.80 \pm 0.01^{b}$ & $6.17 \pm 0.26^{\mathrm{a}}$ \\
\hline 2-Phenyl ethanol (mg/L) & $4.14 \pm 0.37^{b}$ & $2.59 \pm 0.21^{\mathrm{a}}$ & $4.14 \pm 0.38^{b}$ & $2.57 \pm 0.22^{\mathrm{a}}$ \\
\hline$\alpha$-Methylbenzyl alcohol (mg/L) & $0.06 \pm 0.01^{\mathrm{a}}$ & $0.09 \pm 0.01^{b}$ & $0.08 \pm 0.01^{b}$ & $0.11 \pm 0.01^{c}$ \\
\hline 2-Methyldihydrofuranone (mg/L) & $0.06 \pm 0.00^{\mathrm{a}}$ & $0.09 \pm 0.00^{\mathrm{b}}$ & $0.09 \pm 0.01^{b}$ & $0.12 \pm 0.01^{c}$ \\
\hline Linalool (mg/L) & $0.68 \pm 0.11^{\mathrm{a}}$ & $0.83 \pm 0.01^{\mathrm{a}, \mathrm{b}}$ & $0.84 \pm 0.05^{\mathrm{a}, \mathrm{b}}$ & $0.96 \pm 0.03^{b}$ \\
\hline Linalool oxide cis (mg/L) & $1.13 \pm 0.06^{b}$ & $1.21 \pm 0.04^{b}$ & $0.91 \pm 0.13^{\mathrm{a}}$ & $1.01 \pm 0.03^{a, b}$ \\
\hline 4-Methoxybenzaldehyde (mg/L) & $0.03 \pm 0.00^{\mathrm{a}}$ & $0.04 \pm 0.00^{b}$ & $0.06 \pm 0.01^{c}$ & $0.08 \pm 0.00^{d}$ \\
\hline Hexanal (mg/L) & $1.13 \pm 0.06^{b}$ & $1.21 \pm 0.04^{b}$ & $0.91 \pm 0.13^{\mathrm{a}}$ & $1.01 \pm 0.03^{a, b}$ \\
\hline Heptanal (mg/L) & $1.13 \pm 0.06^{b}$ & $1.29 \pm 0.06^{c}$ & $0.99 \pm 0.03^{\mathrm{a}}$ & $1.08 \pm 0.01^{a, b}$ \\
\hline Nonanal (mg/L) & $0.93 \pm 0.04^{c}$ & $0.99 \pm 0.01^{c}$ & $0.54 \pm 0.05^{a}$ & $0.66 \pm 0.03^{b}$ \\
\hline प-Terpineol (mg/L) & $2.01 \pm 0.21^{\mathrm{a}}$ & $2.64 \pm 0.28^{\mathrm{a}}$ & $2.01 \pm 0.21^{\mathrm{a}}$ & $2.64 \pm 0.28^{\mathrm{a}}$ \\
\hline Benzoic acid (mg/L) & $21.74 \pm 0.88^{\mathrm{a}}$ & $60.49 \pm 7.16^{b}$ & $21.74 \pm 0.88^{\mathrm{a}}$ & $60.49 \pm 7.16^{b}$ \\
\hline Ethyl lactate $(\mathrm{mg} / \mathrm{L})$ & $0.09 \pm 0.01$ & n.d. & $0.09 \pm 0.01$ & n.d. \\
\hline Ethyl octanoate (mg/L) & $2.75 \pm 0.09^{a}$ & $2.40 \pm 0.31^{\mathrm{a}}$ & $2.75 \pm 0.09^{a}$ & $2.40 \pm 0.31^{\mathrm{a}}$ \\
\hline Ethyl decanoate $(\mathrm{mg} / \mathrm{L})$ & $0.92 \pm 0.16$ & n.d. & $0.92 \pm 0.16$ & n.d. \\
\hline Ethyl acetate $(\mathrm{mg} / \mathrm{L})$ & $6.33 \pm 0.18^{b}$ & $4.45 \pm 0.04^{a}$ & $6.33 \pm 0.18^{b}$ & $4.45 \pm 0.04^{\mathrm{a}}$ \\
\hline Isoamyl acetate (mg/L) & $8.51 \pm 0.16^{b}$ & $8.03 \pm 0.01^{\mathrm{a}}$ & $8.51 \pm 0.15^{b}$ & $8.03 \pm 0.01^{\mathrm{a}}$ \\
\hline Acetaldehyde (mg/L) & $4.44 \pm 0.45^{\mathrm{a}}$ & $3.81 \pm 0.94^{\mathrm{a}}$ & $4.44 \pm 0.45^{\mathrm{a}}$ & $3.82 \pm 0.94^{\mathrm{a}}$ \\
\hline Ethyl hexanoate (mg/L) & $2.49 \pm 0.53^{\mathrm{a}}$ & $2.34 \pm 0.46^{\mathrm{a}}$ & $2.48 \pm 0.52^{\mathrm{a}}$ & $2.34 \pm 0.45^{\mathrm{a}}$ \\
\hline Methyl octanoate (mg/L) & $0.41 \pm 0.06^{\mathrm{a}}$ & $0.40 \pm 0.08^{\mathrm{a}}$ & $0.41 \pm 0.06^{\mathrm{a}}$ & $0.40 \pm 0.09^{\mathrm{a}}$ \\
\hline 2-Phenylethyl acetate $(\mathrm{mg} / \mathrm{L})$ & $0.72 \pm 0.15^{\mathrm{a}}$ & $0.59 \pm 0.01^{\mathrm{a}}$ & $0.72 \pm 0.15^{\mathrm{a}}$ & $0.59 \pm 0.01^{\mathrm{a}}$ \\
\hline
\end{tabular}

${ }^{*}$ Different superscripts in the same row show statistically significant difference at $\mathrm{p} \leq 0.05$ 
The total share of typical honey volatile substances was significantly higher in distillates produced by immobilized yeast cells. For acacia honey, typical volatiles are heptanal, cis-linalool oxide (Radović et al., 2001) and hexanal (Manyi-Loh et al., 2011a) and, as shown in Table 1, they are more dominant in acacia honey brandy compared to chestnut brandy, regardless of fermentation procedure.
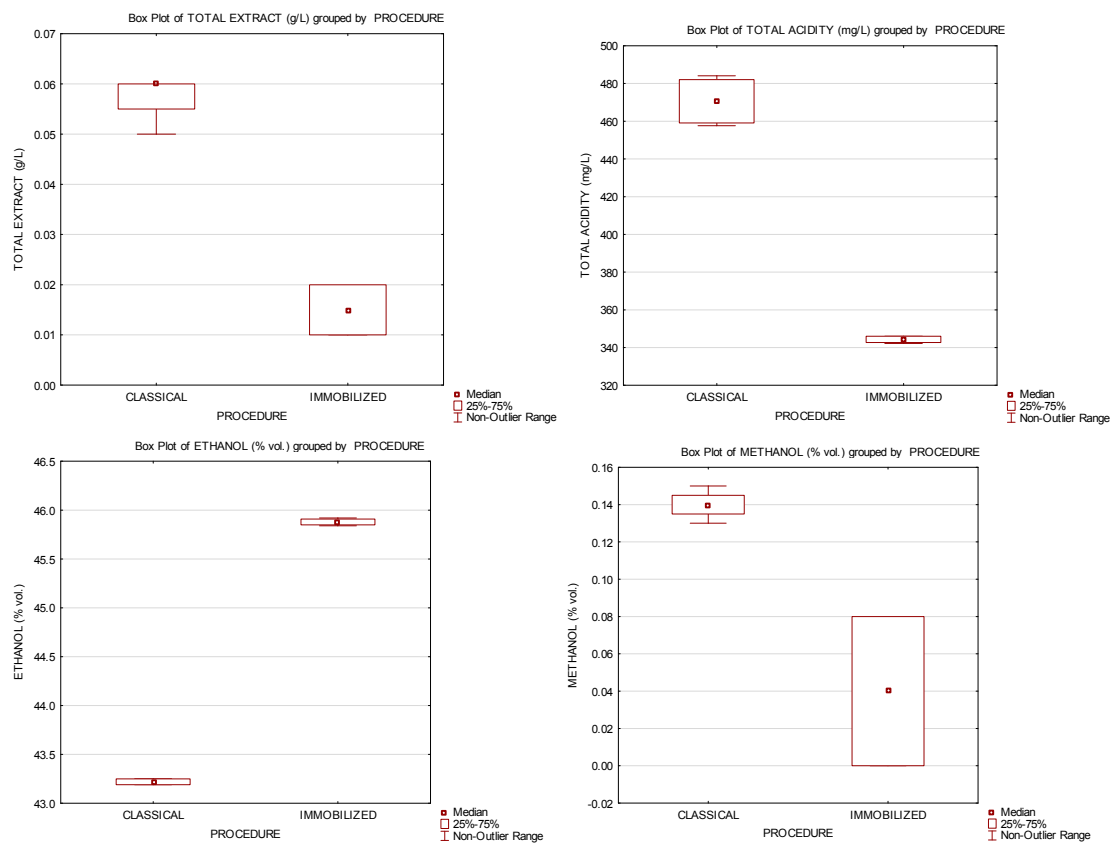

Figure 1. Statistical difference of basic chemical composition between samples produced by classical procedure and by immobilized yeast, regardless of honey type used as a raw material $(\mathbf{p} \leq \mathbf{0 . 0 5})$

Slika 1. Statistička razlika u osnovnom kemijskom sastavu između uzoraka proizvedenih klasičnim postupkom i pomoću imobiliziranih stanica kvasaca, ne uzimajući u obzir vrstu meda od kojeg su proizvedeni ( $p \leq 0.05)$

If fermentation influence is considered, higher proportions of these compounds are present in samples fermented with immobilized yeast cells (Fig. 2 and 3), although it has to be noted that hexanal differences were less pronounced. Marker compounds of chestnut honey: $\alpha$-methylbenzyl alcohol and 2-methylhydrofuranone (Radović et al., 2001) were markedly higher in immobilized yeast-fermented samples (Fig. 2 and 3).
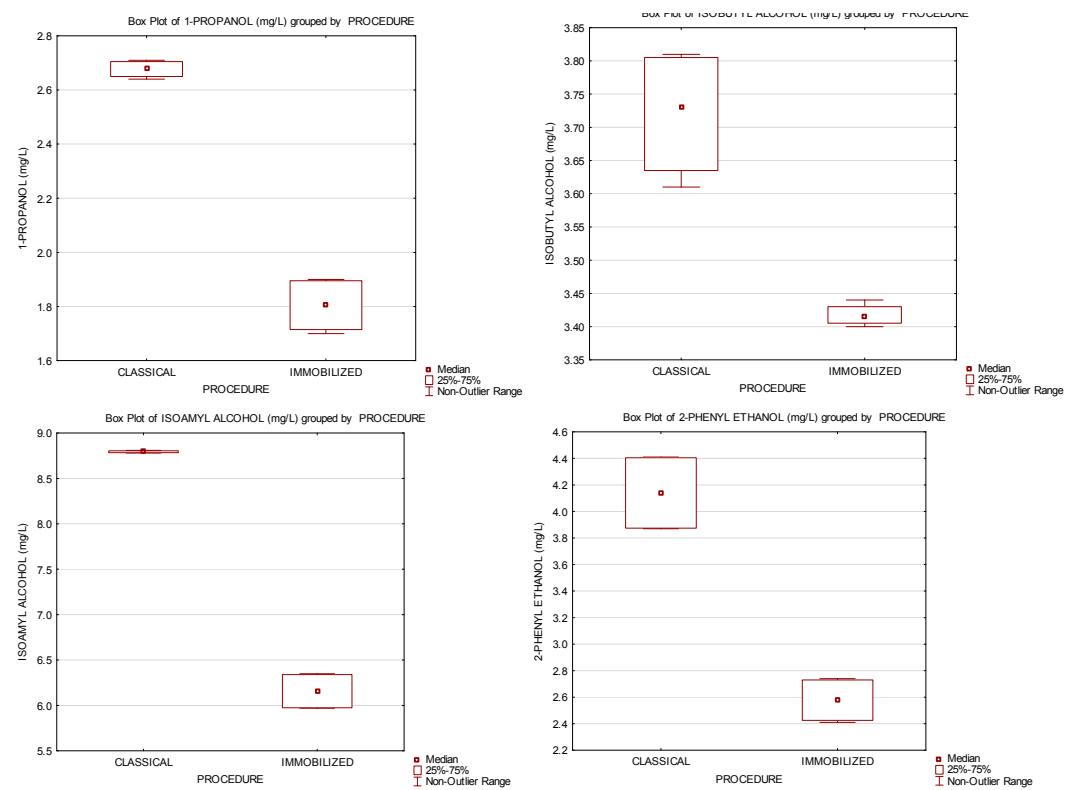

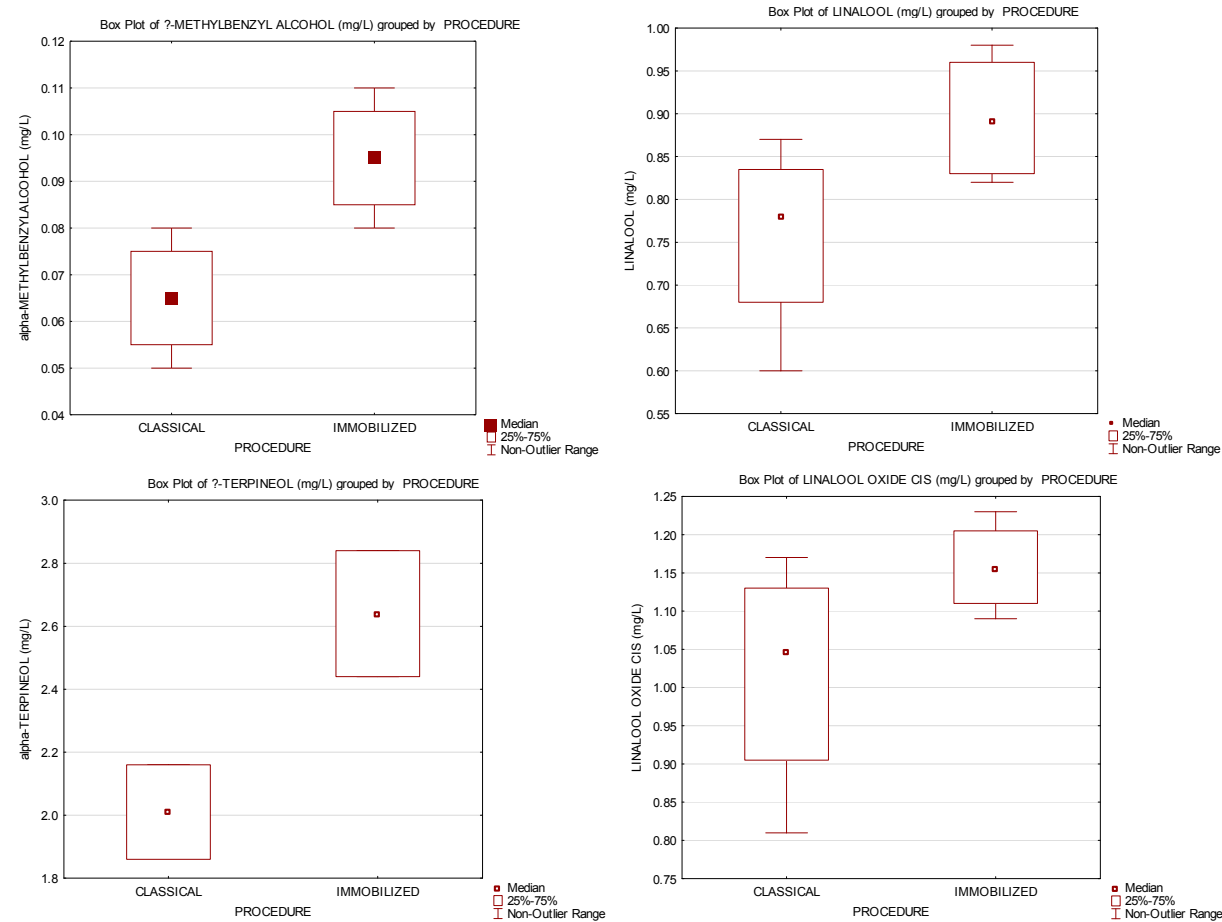

Figure 2. Influence of the fermentation procedure (classical or with immobilized yeast cells) on alcohols affecting aroma of honey brandy, regardless of the honey type used as a raw material $(p \leq 0.05)$

Slika 2. Utjecaj procesa fermentacije (klasični ili s imobiliziranim stanicama kvasca) na udio alkohola koji utječu na aromu medne rakije ( $p \leq 0.05)$, ne uzimajući u obzir vrstu meda od kojega su proizvedeni

From the basic aroma profile of distillates (Table 1 ), it is visible that the content of main components affecting the aroma profile has been reduced when using the fermentation process with immobilized yeast cells. It can result in reduced distillate characteristics.
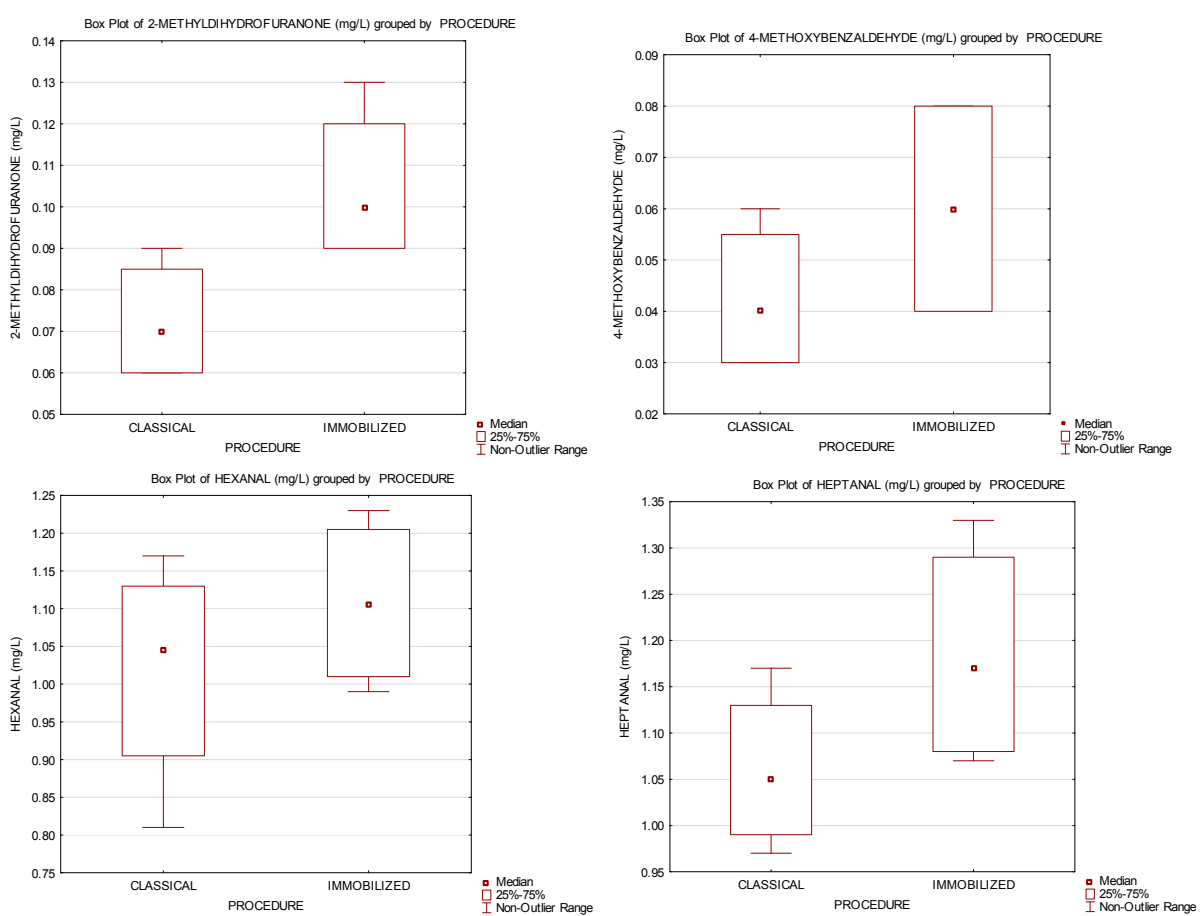

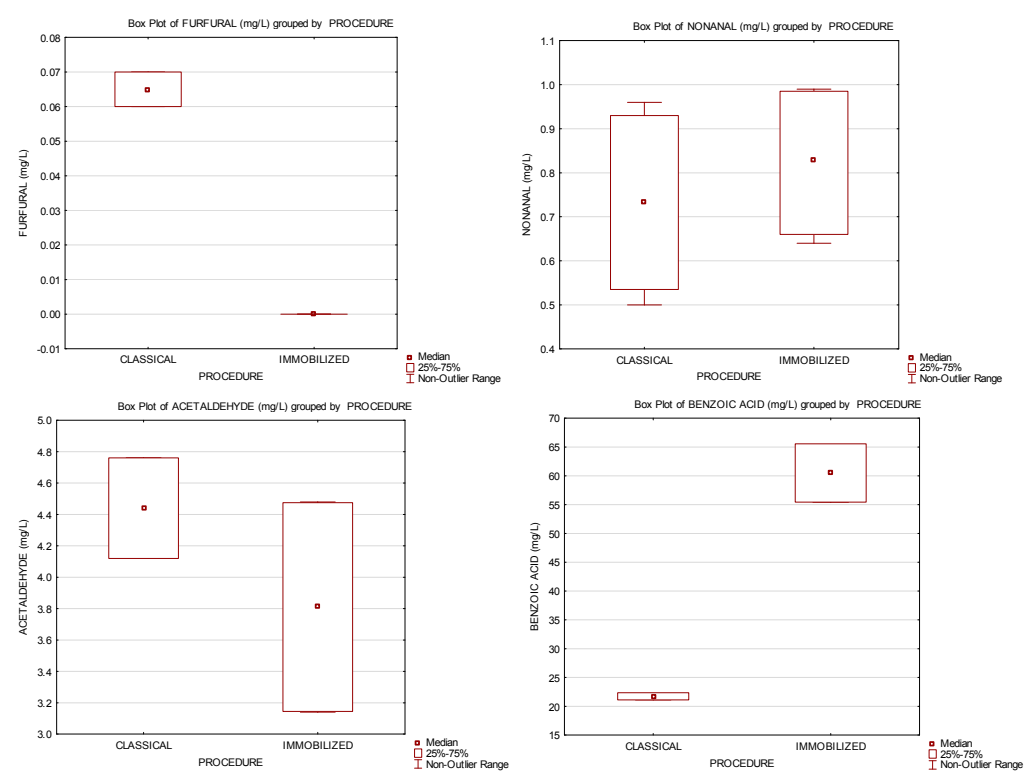

Figure 3. Influence of the fermentation procedure (classical or with immobilized yeast cells) on identified aldehydes, ketones and acid affecting aroma of honey brandy, regardless of the honey type used as a raw material $(\mathbf{p} \leq \mathbf{0 . 0 5 )}$

Slika 3. Utjecaj procesa fermentacije (klasični ili s imobiliziranim stanicama kvasca) na udio identificiranih aldehida, ketona i kiselina koji utječu na aromu medne rakije ( $p \leq 0.05)$, ne uzimajući u obzir vrstu meda od kojega su proizvedeni

Esters play major role in aroma perception, giving fruity smell to alcoholic beverages (Plutowska et al., 2010). Fig. 4 shows that they are present in significantly higher proportions in classically fermented brandies, giving them deeper aroma (Fenaroli, 2002; Plutowska and Wardencki, 2009). In addition, furfural, giving sweet aroma to honey (Manyi-Loh et al., 2011a) was also present in higher concentration in classically fermented brandies (Fig. 3). Aldehydes are generally perceived as compounds with negative aroma characteristics of spir- its (Plutowska et al., 2010). If fermentation procedures are considered, regardless of honey type (Fig. 3), it is clear that immobilized yeast cell-fermentation results in higher proportion of these compounds.

The average content of analysed aroma compounds did not differ significantly between the two honeys used in the research, because heating reduces honey aroma and probably floral fingerprint is lost during distillation process.
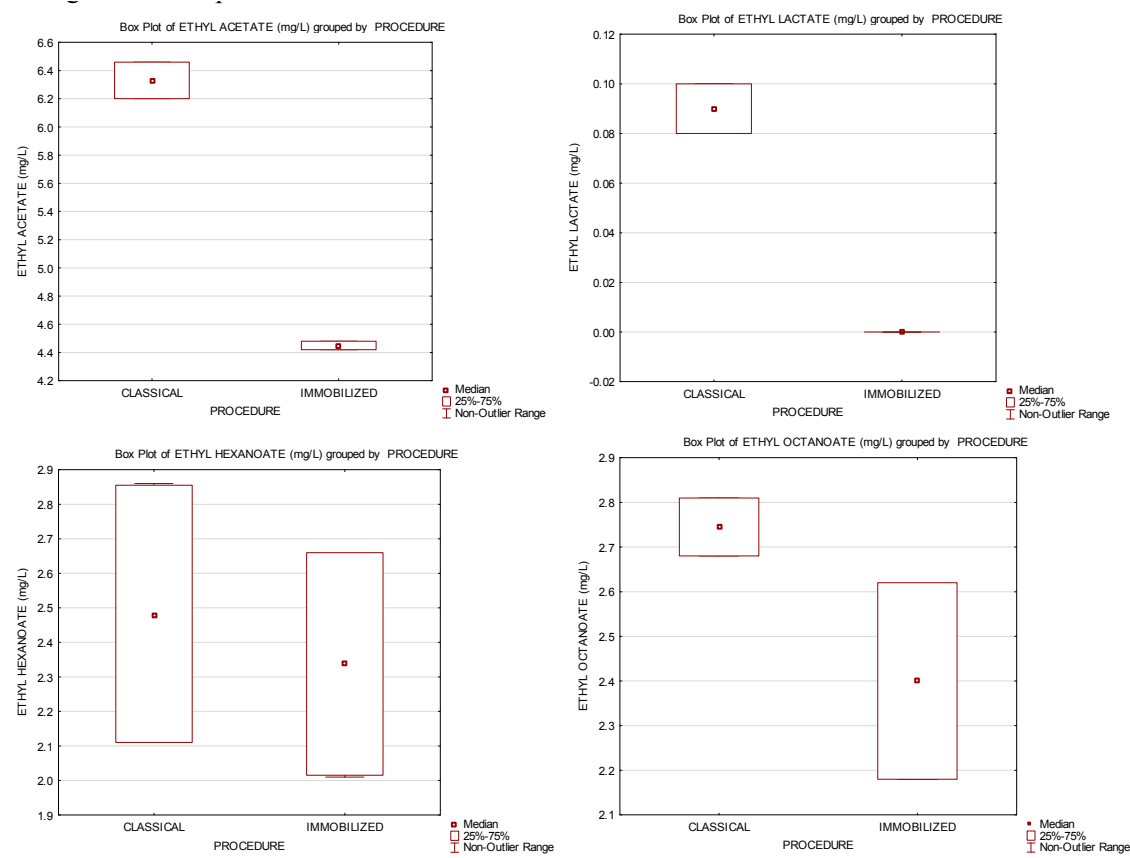

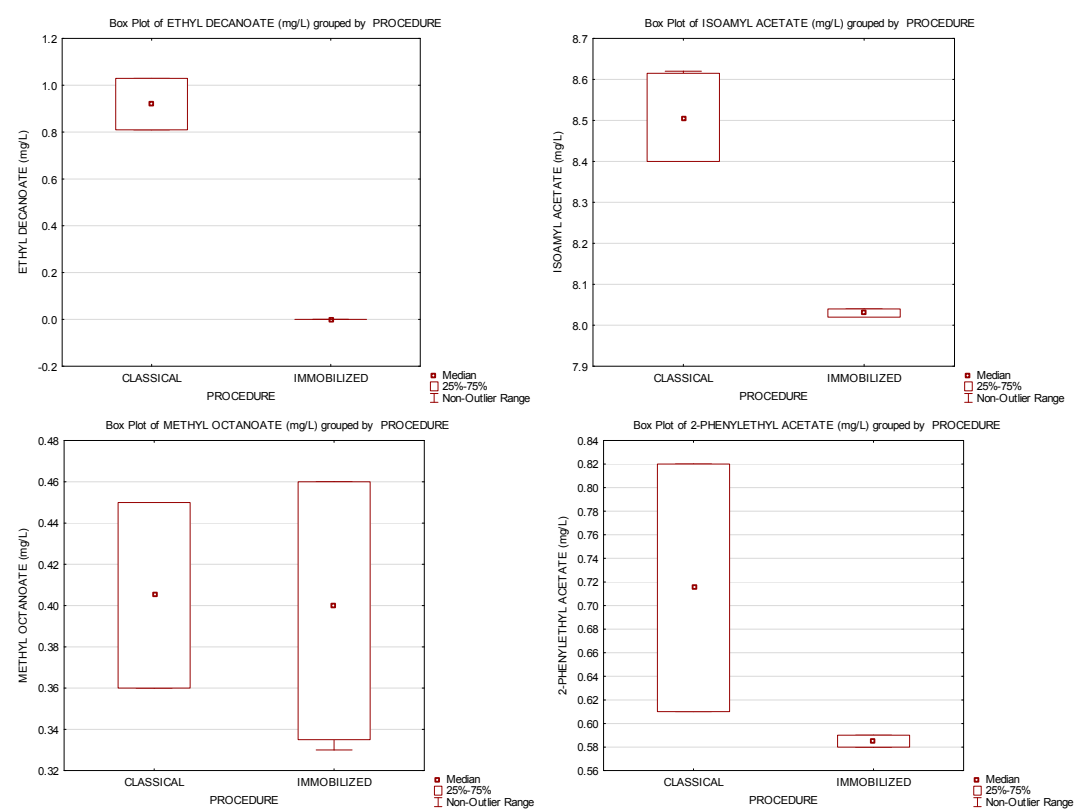

Figure 4. Influence of the fermentation procedure (classical or with immobilized yeast cells) on identified esters affecting aroma of honey brandy $(\mathbf{p} \leq \mathbf{0 . 0 5})$, regardless of the honey type used as a raw material

Slika 4. Utjecaj procesa fermentacije (klasični ili s imobiliziranim stanicama kvasca) na udio identificiranih estera koji utječu na aromu medne rakije ( $p \leq 0.05)$, ne uzimajući u obzir vrstu meda od kojega su proizvedeni

The differences between samples produced by different fermentation procedure did not reflect significantly on sensory properties determined by trained sensory panel (Fig. 5). All assessed parameters: colour, clearness, odour and taste were only slightly lower for immobilised yeast-fermented brandy and not statistically significant. An important investigation about sensory analysis of different honey spirits was conducted by the Anjos et al. (2017). By tasting the fourteen dif- ferent honey spirit samples a list of 98 attributes were obtained. They included 10 attributes related to the visual attributes, 53 attributes regarding to the orthonasal aroma and 33 related to the flavor. They concluded that the most important orthonasal attributes in the tested spirits were fruity, floral and sweet, as well as vegetative/herbaceous. However, the most frequent gustatory attributes are smoky, sweet and bitter.

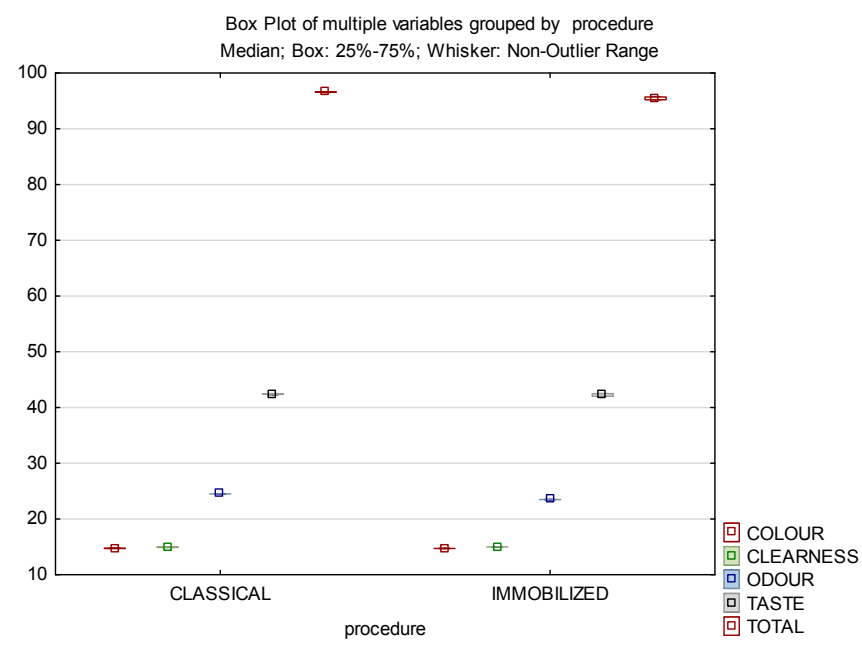

Figure 5. Influence of the fermentation procedure (classical or with immobilized yeast cells) on sensory properties of honey brandy (determined according to German DLG model) $(p \leq 0.05)$, regardless of the honey type used as a raw material

Slika 5. Utjecaj procesa fermentacije (klasični ili s imobiliziranim stanicama kvasca) na senzorska svojstva medne rakije (određena prema njemačkome DLG modelu) ( $p \leq 0.05)$, ne uzimajući u obzir vrstu meda od kojega su proizvedeni 


\section{CONCLUSION}

The results obtained in this research show that immobilised yeast fermentation in production of honey brandy results in higher content of volatile compounds characteristic for honey type, but somewhat negatively influences volatile compounds responsible for the aroma. It is reflected in ester concentration decreasing and aldehyde concentration increasing compared to classically fermented spirit. These changes, although statistically significant do not notably influence sensory properties of the brandy.

The immobilised yeast cell fermentation is a promising tool in production of honey brandy. However, additional research is required to determine the potential of reuse of immobilised yeast cells and economical aspect of the process regarding its application in industry.

The applied distillation process resulted in no significant influence of honey type on the aroma of obtained distillates, pointing out that constant quality could be obtained by the process regardless of honey type. However, this should be confirmed by a larger number of honey types.

\section{ACKNOWLEDGEMENT}

Authors are very grateful to Osijek-Baranja County for financial support of the research through the project Improvement and Standardisation of Production of Honey Mead and Honey Brandy.

\section{REFERENCES}

1. AOAC. (1995). Official Methods of Analysis (16 $6^{\text {th }}$ ed.), Association of Official Chemists, Arlington, VA, USA.

2. Anjos, O., Frazão, D., \& Caldeira, I. (2017). Physicochemical and Sensorial Characterization of Honey Spirits. Foods, 6(8), 58. https://doi.org/:10.3390/foods6080058

3. Arrieta-Garay, Y., García-Llobodanin, L., Pérez-Correa, J. R., López-Vázquez, C., Orriols, I., \& López, F. (2013). Aromatically enhanced pear distillates from blanquilla and conference varieties using a packed column. Journal of Agricultural and Food Chemistry, 61(20), 4936-4942. https://doi.org/10.1021/jł304619e

4. Arrieta-Garay, Y., López-Vázquez, C., Blanco, P., PérezCorrea, J. R., Orriols, I., \& López, F. (2014a). Kiwi spirits with stronger floral and fruity characters were obtained with a packed column distillation system. Journal of the Institute of Brewing, 120(2), 111-118. https://doi. org/10.1002/jib.117

5. Bašić, Ž. (2006). Voda života- povijest proizvodnje alkoholnih pića. Šibenik: Tiskara Malenica.

6. Bouseta, A., Collins, S., \& Dufour, J. P. (1992). Characteristics aroma profiles of unifloral honeys obtained with a dynamic head-space GC-MS system. Journal of Apicultural Research, 31(2): 96-109. https:// doi.org/10.1080/00218839.1992.11101268

7. Burdock, G. A. (Ed.) (2002). Fenaroli's Handbook of Flavor Ingredients $4^{\text {th }}$ ed., CRC Press, Florida, USA.
8. EEC. (2000). Council Regulation 2870/00 laying down Community reference methods for the analysis of spirit drinks. Official Journal of European Communities, L333.

9. EEC. (2008). Council Regulation $110 / 2008$ on the definition, description and presentation of spirit drinks. Official Journal of European Communities, L39.

10. Gupta, J. K., \& Sharma, R. (2009). Production technology and quality characteristics of mead and fruit-honey wines: A review. Natural Product Radiance, 8(4): 345355

11. Jellinek, G. (1985). Sensory Evaluation of Food, Theory and Practice. Ellis Horwod international publishers in since and technology: Chichester, pp 252-255.

12. Jerković, I., \& Marijanović, Z. (2009). A short review of headspace extraction and ultrasonic solvent extraction for honey volatiles fingerprinting. Croatian Journal of Food Science and Technology, 1(2): 28-34. https://hrcak. srce.hr/53251

13. Jerković, I., Mastelić, J., Marijanović, Z., Klein, Ž., \& Jelić, M. (2007). Comparison of hydrodistillation and ultrasonic solvent extraction for the isolation of volatile compounds from two unifloral honeys of Robinia pseudoacacia L. and Castanea sativa L. Ultrasonics Sonochemistry, 14(6): 750-756. https://doi.org/10.1016/j.ultsonch.2006.12.014

14. Koch, J. (1986). Getränkebeurteilung. Eugen Ulmer GmbH Co.: Stuttgart, pp 95-96.

15. Lukić, I., Miličević, B., Tomas, S., Radeka, S., \& Peršurić, Đ. (2012). Relationship between volatile aroma compounds and sensory quality of fresh grape marc distillates. Journal of Institute of Brewing, 118(3): 285-294. https://doi.org/10.1002/jib.39

16. Manyi-Loh, C. E., Ndip, R. N., \& Clarke, A. M. (2011a). Volatile Compounds in Honey: A Review on Their Involvement in Aroma, Botanical Origin Determination and Potential Biomedical Activities. International Journal of Molecular Sciences, 12(12), 9514-9532. https:// doi.org/10.3390/ijms12129514

17. Manyi-Loh, C. E., Ndip, R. N., \& Clarke, A. M. (2011b). Identification of volatile compounds in solvent extracts of honeys produced in South Africa. African Journal of Agricultural Research, 6(18): 4327-4334. https://doi. org/10.5897/AJAR11.754

18. Miličević, B., Lukić, I., Babić, J., Šubarić, D., Miličević, R., \& Ačkar, Đ. (2012). The influence of fermentation process with immobilized yeast cells on quality of tangarine distillates. Glasnik zaštite bilja, 35(5): 68-75.

19. Miličević, B., Ačkar, Đ., Babić, J., Jozinović, A., Miličević, R., Oroz, M., Šubarić, D. (2017). Impact of the fermentation process with immobilized yeast cells on the aroma profile and sensory quality of distillates produced from two fig (Ficus carica L.) cultivars. Poljoprivreda, 23(1): 49-55. https://doi.org/10.18047/poljo.23.1.8

20. Nedović, V., Gibson, B., Mantzouridou, T. F., Bugarski, B., Djordjević, V., Kalušević, A., ... \& Yilmaztekin, M. (2015). Aroma formation by immobilized yeast cells in fermentation processes. Yeast, 32(1): 173-216. https:// doi.org/10.1002/yea.3042

21. Nykanen, L., \& Suomalainen, H. (1983). Aroma of Beer, Wine and Distilled Alcoholic Beverages. Akademieverlag: Berlin, Germany. 
22. Paine, A. J., \& Dayan, A. D. (2001). Defining a tolerable concentration of methanol in alcoholic drinks. Human and Experimental Toxicology, 20(11), 563-568. https:// doi.org/10.1191/096032701718620864

23. Pohanka, M. (2016). Toxicology and the biological role of methanol and ethanol: Current view. Biomedical Papers, 160(1): 54-63. https://doi.org/10.5507/bp.2015.023

24. Plutowska, B., Biernacka, P., \& Wardencki, W. (2010). Identification of volatile compounds in raw spirits of different organoleptic quality. Journal of Institute of Brewing, 116(4), 433-439. https://doi. org/10.1002/j.2050-0416.2010.tb00794.x

25. Plutowska, B., \& Wardencki, W. (2009). Headspace solid-phase microextraction and gas chromatographyolfactometry analysis of raw spirits of different organoleptic quality. Flavour and Fragrance Journal, 24(4), 177-185. https://doi.org/10.1002/ffj.1930

26. Radović, B. S., Careri, M., Mangia, A., Musći, M., Gerboles, M., \& Anklam, E. (2001). Contribution of dynamic headspace GC-MS analysis of aroma compounds to authenticity testing of honey. Food Chemistry, 72(4), 511-520. https://doi.org/10.1016/S03088146(00)00263-6
27. Rodrigues-Bencomo, J., Perez-Correa, J. R., Orriols, I., Lopez, F. (2016). Spirit Distillation Strategies for Aroma Improvement Using Variable Internal Column Reflux. Food and Bioprocess Technology, 9(11): 1885-1892. https://doi.org/10.1007/s11947-016-1776-0

28. Rodríguez Madrera, R., \& Suárez Valles, B. (2007). Determination of volatile compounds in cider spirits by gas chromatography with direct injection. Journal of Chromatographic Science, 45(7), 428-434. https://doi. org/10.1093/chromsci/45.7.428

29. Silva, I. L., Pagliarini, M. A., Chagas, T.E., Frühauf, M., Kempka, A. P., \& Dornelles, R. C. P. (2017). Effect of supplementation with pollen and brewer's yeast in the fermentation and in the physicochemical properties of honey spirits. International Food Research Journal, 24(3), 1124-1134.

30. Wardencki, W., Chmiel, T., Dymerski, T., Biernacka, P., \& Plutowska, B. (2009). Application of gas chromatography, mass spectrometry and olfactometry for quality assessment of selected food products. Ecological Chemistry and Engineering, 16(3), 287-300.

\section{AROMATSKI PROFIL I SENZORSKA KVALITETA MEDNE RAKIJE PROIZVEDENE FERMENTACIJOM S IMOBILIZIRANIM KVASCIMA}

\section{SAŽETAK}

Hlapljivi aromatski sastojci u medu karakteristični su za svaki med i stoga bi mogli značajno utjecati na kvalitetu medne rakije. Osim toga, tijekom fermentacije, kvasci sintetiziraju hlapljive spojeve koji, također, utječu na aromu i kvalitetu rakije.

Cilj ovog istraživanja bio je procijeniti utjecaj fermentacije $s$ imobiliziranim stanicama kvasca na aromu mednih rakija proizvedenih od meda bagrema i kestena. Aromatski profil određen je primjenom GC/FID-a, a senzorska analiza provedena je prema njemačkome DLG modelu. Rezultati su pokazali da primjena tehnike $s$ imobiliziranim kvascima rezultira nižim udjelom estera, ali i značajno višim udjelom spojeva podrijetlom iz meda.

Ključne riječi: imobilizirane stanice kvasca, medna rakija, aroma, senzorska kvaliteta

(Received on 8 May 2018; accepted on 13 November 2018 - Primljeno 08. svibnja 2018.; prihvaćeno 13. studenoga 2018.) 